Abd Hair Awang
Rahmah Ismail $^{2}$
Zulridah Mohd Noor
UDK 377:331.101.6

Preliminary paper

Prethodno priopćenje

\title{
TRAINING IMPACT ON EMPLOYEE'S JOB PERFORMANCE: A SELF EVALUATION
}

\begin{abstract}
Nurturing a high-quality, knowledgeable and innovative human capital with strong moral and ethical values has become a new source of driving the nation's productivity growth and competitiveness. Therefore, Human Resource Development Council (HRDC) was established in 1992 to generate lifelong learning in workplace setting to improve labor productivity, technology transfer and innovation. In 2002 it was renamed as Human Resource Development Limited (HRDL). All registered employers with HRDL are eligible for the employees training grants. The total approved training places and disbursement of training grants had increased over the years. This paper investigates to what extent the training programs improve employee knowledge, skills, works behavior and job performance, and what are the significant training related factors influencing job performance. The paper is based on data collected through self-reported survey on 1200 employees (458 responded) at hotels, resorts and ICTs companies in four selected states. Out of the responses, 73 percent attended various training programs coordinated by HRDL. The result shows that, in general, the training programs improve knowledge, skills and positive work behavior of employees. Multiple linear regression analysis supports the hypothesis that training related variables have positive impact on employees' job performance except cognitive competence.
\end{abstract}

Key words: Training, competence, job performance, employee quality

JEL classification code: J24 - Human Capital; Skills, O15 - Human Resources; Human Resource Development J08 - Labor Economics Policies

\section{INTRODUCTION}

Malaysia is moving up the competitiveness rankings by seven spots to the 25th place in the Growth Competitiveness index in 2005, as compared to 2004. In terms of the Business Competitiveness Index, Malaysia's ranking moved upward to $20^{\text {th }}$ place. Malaysia also places 26th in the World Economic Forum's (WEF) Global Competitiveness Index (GCI) rankings for 2006 (Claros et. al 2007; Porter, Schwab and Martin 2006; Claros, Porter and Schwab 2005). Currently Malaysia has moved up to the $19^{\text {th }}$ place in the World Competitiveness Yearbook 2008 published by the International Institute for Management Development (IMD) based in Switzerland (IMD, 2008). The competitiveness of nation and companies in the knowledge-based economy today lies more on their knowledge and intellectual capital than on other resources as mentioned in the Ninth Malaysia Plan 2006-2010 (Malaysia 2006). Local researchers (such as Fong Chan Ong, 2006; Kanapathy, 1997; Tan and Gill, 2000) have recognized that knowledge workers are the most critical element in developing advance technologies, improving productivity and continuing to attract foreign direct investment

\footnotetext{
${ }^{1}$ Center of Social, Development and Environmental Studies, Faculty of Social Sciences \& Humanities, Universiti Kebangsaan Malaysia, 43600 UKM Bangi, Selangor Darul Ehsan, Malaysia, hair@ukm.my, tel +603 89215481 fax +60389213334

${ }^{2}$ Center of Economic Studies, Faculty of Economics and Business Management, Universiti Kebangsaan Malaysia, 43600 UKM Bangi, Selangor Darul Ehsan, Malaysia, rahis@pkrisc.cc.ukm.my, oe@pkrisc.cc.ukm.my
} 
(FDI). These circumstances point to the importance of human resources as factors of investment, economic development and as key element of competitiveness (Garelli, 2002). Therefore, the priority efforts must be given to develop high-quality, knowledgeable and innovative human capital with strong moral and ethical values to perform tasks efficiently and effectively (Prime Minister's Department, 2008). With regards to the above, the private sector employers are encouraged to retrain and upgrade the skill of their employees. Human Resource Development Limited (HRDL) was set up as a mechanism for stimulating and strengthening organizational learning culture among private companies in Malaysia. This article addressed two main questions. First, does training programs improve knowledge, skills and work behavior of the participant? Second, does training affect on job performance?

\section{HUMAN RESOURCE DEVELOPMENT FUND (HRDF)}

Human resource development (HRD) act was established in 1992 and enforced in January 1993. The enforcement of this act led to the formation of Human Resource Development Fund (HRDF) and Human Resource Development Council (HRDC) as a coordinator (HRDF, 2008). In 2002 HRDC was renamed as Human Resource Development Limited (HRDL). In the early implementation, HRD act only covered employers with 50 and above Malaysian citizen employees in the manufacturing sector. Every employer must register with HRDL and pay one percent of the monthly wages of the employee. The wages of employees are not permitted to be deducted for the payment of the levy (HRDF 2008). However with effect from January 1995, the coverage was extended to employers with 10 to 49 employee and paid-up capital of RM2.5 million and above (HRDF 2005). The establishment of the HRDL aims at upgrading the knowledge and skills of workers, equipping workers with the latest and specific skills, producing multi-skilled workers, facilitating the transfer technology, improving productivity and value-added operations, preventing worker's skills from becoming obsolete and enhancing the training culture amongst employers (HRDF, 2008).

In 2007, there was an additional sector covered under the Act, namely, the Commercial Land Transport Sector. The total number of registered employers was increased from 10,261 in year 2006 to 10,780 in year 2007 (HRDF, 2008). The total amount of levy collection also increases over the years with 23 percent of annual growth rate. In year 2008, total amount of levy collection was RM323.39 million as shown in Chart 1.

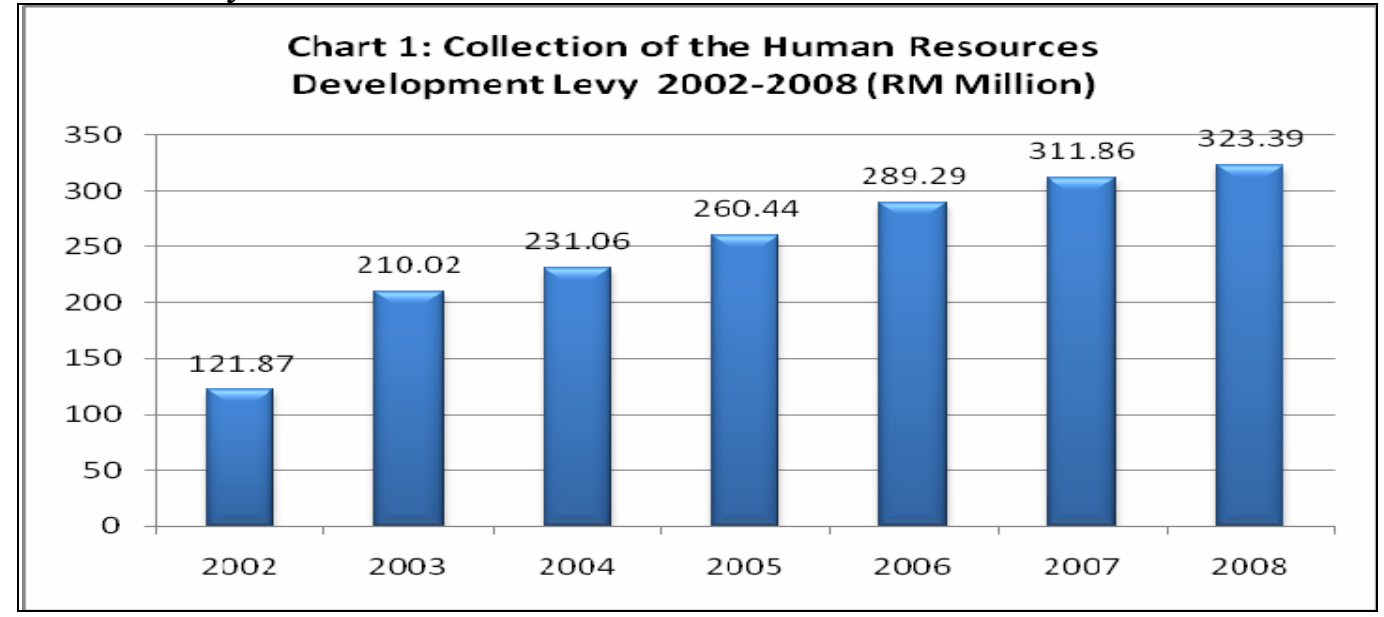

Source: HRDF/Human Resource Development Fund (2005, 2008).

Registered employers with HRDL and pay the levy are eligible to apply for training grants in the area of direct benefit to their employees and companies. Currently there are ten training schemes and employers are encouraged to utilize their levy payments. The training schemes consist of subsidize training scheme (SBL), Special-SBL scheme (SBL-Special), 
approved training scheme (PROLUS), annual training plan scheme (PLT), training provider agreement scheme (PERLA), purchase of training aids and set up training rooms, computer based training scheme (CBT), set up computer training units, apprenticeships training scheme and joint training scheme (HRDF 2005). In term of disbursement of training grants, there was an increase of RM129.73 million (81.9 percent) from RM158.31 million in year 2002 to RM288.04 million in year 2008 (Chart 2).

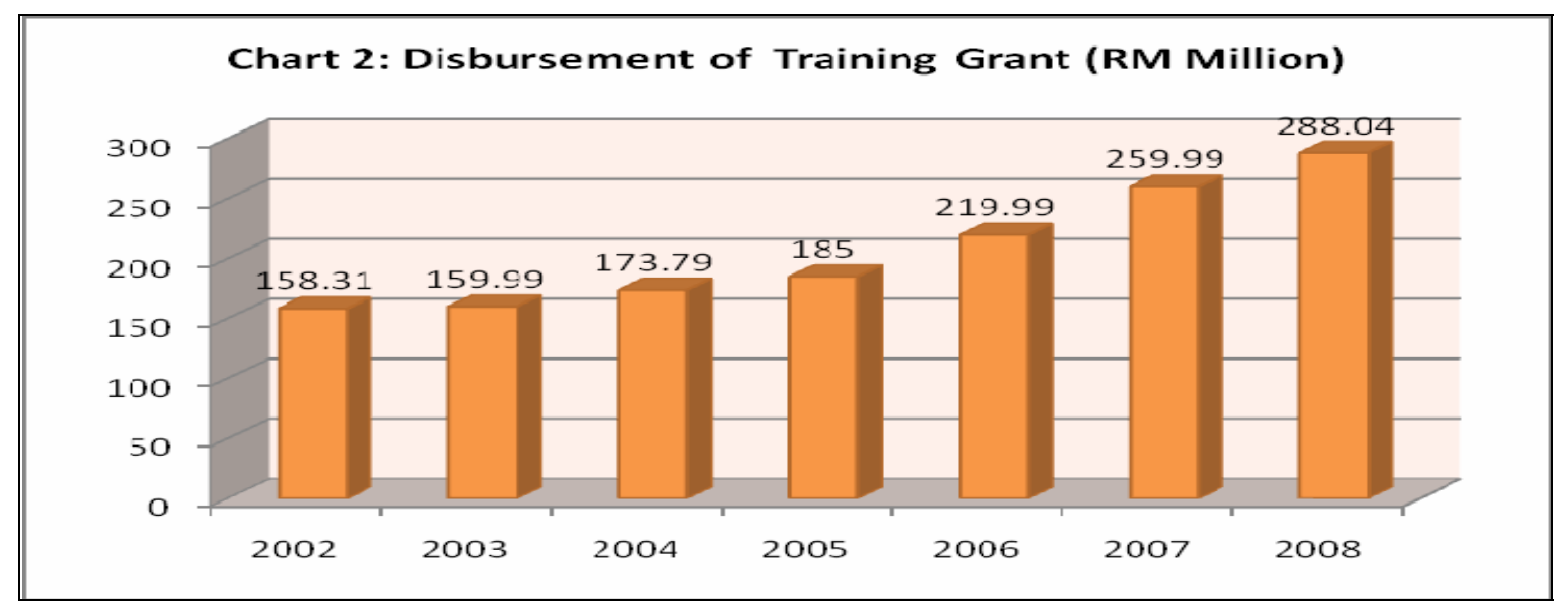

Source: HRDF/ Human Resource Development Fund (2005, 2008).

Chart 3 showed the total approved training places had increased 75.3 percent from 420,008 in 2002 to 736,410 in 2008 . On average the annual growth rate was 10.8 percent. All registered employers are eligible to choose allowed modes of training as enterprises-based training, institution-based training, industry-managed training centers, co-operative type training and overseas training. The training programs are organized by public and private training agencies. All the training provides are monitored, coordinated and endorsed by HRDL. The numbers of registered employer, levy collection \& training places in hotel and computer services sector have increase over the years as shown in Table 1.

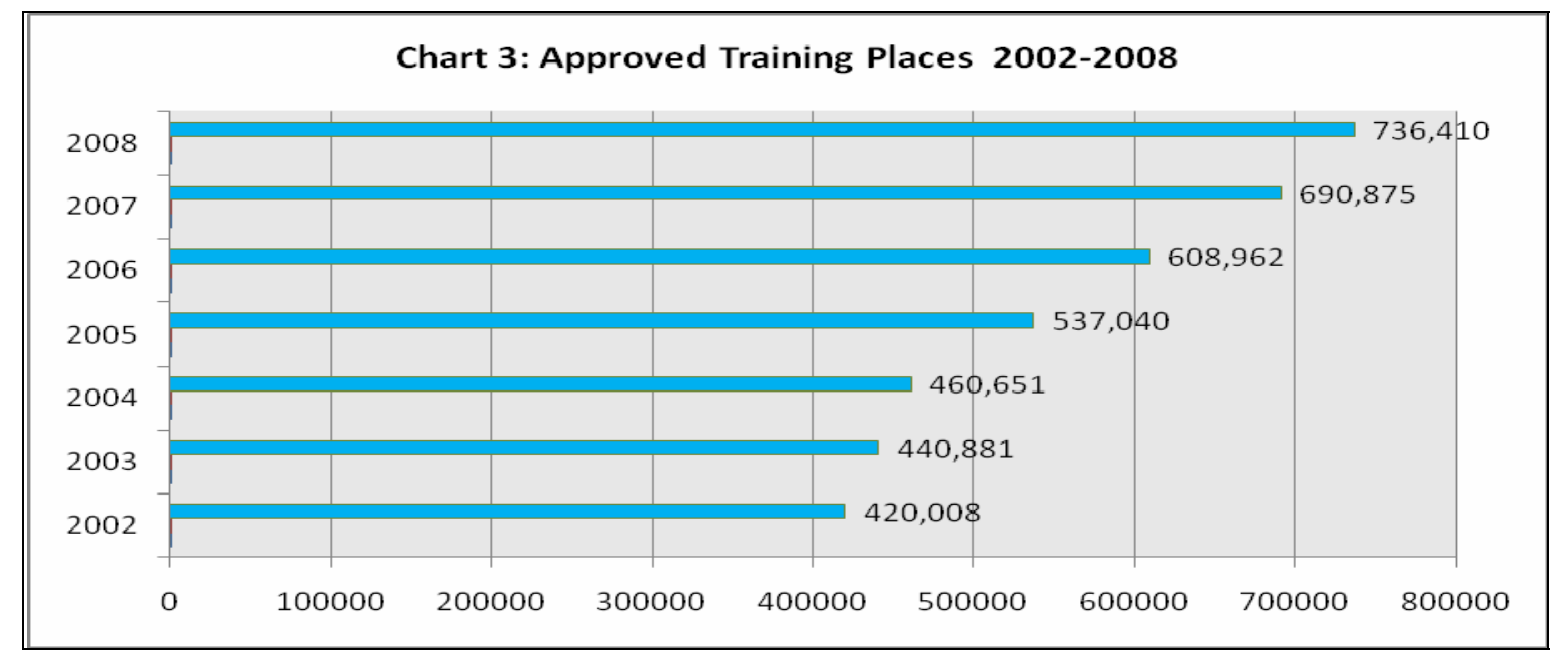

Source: HRDF/Human Resource Development Fund (2005, 2008). 
Table 1:

Numbers of Registered Employer \& Training Places in

Selected Services Sector 2005 - 2007

\begin{tabular}{|c|c|c|c|c|}
\hline \multicolumn{5}{|c|}{ Hotel Industry } \\
\hline Year & $\begin{array}{c}\text { Levy Collection } \\
(\mathrm{RM})\end{array}$ & $\begin{array}{c}\text { Registered } \\
\text { employer }\end{array}$ & $\begin{array}{c}\text { Approved } \\
\text { training places }\end{array}$ & $\begin{array}{c}\text { Registeration of } \\
\text { new employers }\end{array}$ \\
\hline 2007 & $12,673,466.18$ & 792 & 37,710 & 69 \\
\hline 2006 & $11,885,679.74$ & 758 & 40,870 & 27 \\
\hline 2005 & $11,032,257.52$ & 748 & 30,127 & 76 \\
\hline & \multicolumn{5}{|c|}{ Computer services industry } \\
\hline 2007 & $19,101,879.93$ & 676 & 21,935 & 140 \\
\hline 2006 & $17,997,706.94$ & 641 & 17,556 & 65 \\
\hline 2005 & $12,555,300.32$ & 525 & 11,896 & \\
\hline
\end{tabular}

Source: HRDF/Human Resource Development Fund (2005, 2008).

\section{DATA AND METHODS}

A survey of hotels, resorts and ICT's employees was carried out using a structured questionnaire in four selected states (Selangor, Federal Territory, Johor and Pulau Pinang) in Malaysia. The main purpose of the survey was to collect information on the incidence and perceptions of training among multi-racial workers (Malays, Chinese, Indian \& others). Data have been collected through self-reported survey on 1,200 employees (458 responded) who are attended approved training in year 2006-2008. Trained numerators distributed and collected the survey questionnaire. Out of the responses, 334 employees (72.9 percent) attended various training programs coordinated by HRDL. The survey questionnaire was adapted from the Kirkpatrik's training level (reactions, learning outcomes, behavioral changes and results) (1994) taking into account the extensive reviews of relevant research (Al-Khayyat and Elgamal, 1997; Cuthbert, 1996; Ka-shing Woo,1998; Kwan and Ng, 1999; Schmidt 1998; Smith and Wilson, 2002; Strickland, Simons, Harris, Robertson, Harford and Edwards, 2001; Tamkin, 2005; Velde and Cooper, 2000). The survey questionnaire measure the participant perceptions of the actual service and impact received after the training programs. Employees respond to item using a five point likert-type scale ranging from 1 (strongly disagree) to 5 (strongly agree).

A total of four components indicator were identified as the measurement parameters. These are training reactions, learning outcomes, behavioral changes and organizational impact in terms of employee's job performance. We have considered six subjective measures of job performance - work target, product/service quality, product/service defect, customer complaint, job hazard and equipments failure. A pilot test with a group of 20 employees was conducted in September 2008 to determine problem with the instruments. The overall Cronbach alpha $(\propto)$ range of four components indicator in this study was 0.77 to 0.87 . According to George and Mallery (2001) Cronbach alpha $(\propto) 0.7$ is considered acceptable, while 0.8 is good. While, the linear regression model was employed to explain employee's 
job performance by personal endowments (gender, years of schooling and work experience), attributes of training reactions (training contents, financing of the training and trainers quality), learning outcomes (cognitive competencies and technical skills) and behavioral changes (work commitment and work respectfulness).

\section{RESEARCH FRAMEWORK}

A widely accepted Kirkpatrik (1994) classical model, indentified four level of training evaluation; Level One - Reaction, Level Two - Leaning, Level three - Behavior and Level Four - Result. The training system comprises of inputs, process and outcomes (Al-Khayyat and Elgamal, 1997; Barnard, Veldhuis and Van Rooij, 2001; Dumbrell, 2000; Gabbard, 1981; Gasskov, 2000; Grubb and Ryan, 1999; Hanushek, 1986, 1997, 2002; Kim and Harris, 1976; Lynton and Pareek, 2000; McCaslin, 1990; Nelson, 1993; Ziderman, 1997). Inputs of the training program consist of trainer, instructional content and training financing. The training process is the engine of the system. Here the inputs are transformed into actions and outcomes. This is where the teaching and learning occur and required knowledge, skills and behavior changes are introduced to the participants. The trainee's capabilities, personality, motivational factors, previous work experience will affect the learning process. At this stage reaction of service quality of the training program will affect the knowledge, skills and behavior changes of the participants. The main goal of training is to prepare participants for the tasks they are going to perform on their jobs (Barnard, Veldhuis and Van Rooij, 2001; Holton and Trott, 1996; Tamkin, 2005). These effects on the participant refer to the increments in knowledge, skills and attitudes that required in the workplace. The needed impact of training to the company operations is improvement in employee's job performance.

\section{RESULT AND DISCUSSION}

This section presents descriptive statistics and explains the background of respondents and HRDF training programs attended by employees in this study as shown in Table 2. More than half (56.6 percent) of the respondents are female. On average their age are 32 years $(\mathrm{M}=31.58, \mathrm{SD}=6.970)$, with the eldest is 56 years and the youngest is 20 years old. The majority of the employees are Malays ( 52.4 percent), followed by Chinese ( 33.5 percent) and Indian (12.3 percent). In terms of marital status, 60.8 percent of them are married and 38.9 percent are still single. 
Table 2:

\begin{tabular}{|c|c|c|}
\hline \multicolumn{3}{|c|}{ Employees' Demographics Profile } \\
\hline & Frequency & Percent \\
\hline $\begin{aligned} \text { Gender } & \\
\text { - } & \text { Male } \\
\text { - } & \text { Female }\end{aligned}$ & $\begin{array}{l}145 \\
189\end{array}$ & $\begin{array}{l}43.4 \\
56.6\end{array}$ \\
\hline $\begin{aligned} & \text { Race } \\
& \text { - } \text { Malay } \\
& \text { - } \text { Chinese } \\
& \text { - } \text { Indian } \\
& \text { - Others } \\
&\end{aligned}$ & $\begin{array}{c}175 \\
112 \\
41 \\
6\end{array}$ & $\begin{array}{c}52.4 \\
33.5 \\
12.3 \\
1.8 \\
\end{array}$ \\
\hline $\begin{array}{c}\text { Marital status } \\
\text { - Bachelor } \\
\text { - Married } \\
\text { - Widow }\end{array}$ & $\begin{array}{c}130 \\
203 \\
1 \\
\end{array}$ & $\begin{array}{c}38.9 \\
60.8 \\
0.3 \\
\end{array}$ \\
\hline Age & $\begin{array}{l}\text { Min: } 20 \text { years } \\
\text { Max: } 56 \text { years }\end{array}$ & Avg: 32 years \\
\hline
\end{tabular}

Table 3 revealed that most of the employees hold a bachelors degree, 21.0 percent of them are diploma holders and 33.5 percent have SPM or STPM. Majority of the employees have been trained at local educational and training institutions. Only 11.2 percent hold foreign academic qualifications.

Table 3:

\section{Employees’ Academic Qualifications}

\begin{tabular}{|c|c|c|}
\hline Academic qualification & & \\
- MCE or HSC & 112 & 33.5 \\
- Diploma holder & 70 & 21.0 \\
- Bachelor degree & 140 & 41.9 \\
- Master degree & 6 & 1.8 \\
- PhD & - & 1.8 \\
- Others & 6 & \\
\hline Type of educational institution & 26 & 7.8 \\
- Foreign educational institution & 274 & 1.2 \\
- Local educational institution & 37 & 1.0 \\
\hline
\end{tabular}

As shown in Table 4, 13.5 percent of the employees earn less than MYR1,000 a month, 18.6 percent between MYR 1,001 and MYR 1,500, 17.4 percent between MYR 1,500 and MYR 2,000 and 24.0 percent between MYR 2,001 and MYR 2,500. Table 4 also indicates, on average their tenure in the current company is 6 years $(\mathrm{M}=5.82, \mathrm{SD}=4.837)$, with the maximum 35 years service and minimum of one year. In terms of employment status 93.4 percent hold permanent posts, 3.0 percent hold a temporary posts and the rest are working on the contract basis. 
Table 4:

\begin{tabular}{|l|c|c|}
\multicolumn{3}{|c|}{ Current Salary and Employment Profile } \\
\hline Monthly Earning & Frequency & Percent \\
- Less than MYR1,000 & 45 & 13.5 \\
- MYR1,001 - MYR1,500 & 62 & 18.6 \\
- MYR1,501 - MYR2,000 & 58 & 17.4 \\
- MYR2,001 - MYR2,500 & 80 & 24.0 \\
- MYR2,501 - MYR3,000 & 44 & 13.2 \\
- More than MYR3,001 & 45 & 13.5 \\
\hline Job's status & 312 & \\
- Permanent & 10 & 93.4 \\
- Temporary & 12 & 3.0 \\
- Contract & & 3.6 \\
\hline Work experience & Min: 1 years & Avg: 6 years \\
\hline
\end{tabular}

\section{Participation in HRDL Training Program}

The most popular training courses are management and supervisory (36.9 percent), followed by technical skills (15.0 percent), occupational health, safety and environmental protection courses (14.0 percent) and teamwork and motivation (13.6 percent). However a few of them attended ccommunications and customer services and sales and marketing courses as shown in Table 5. Almost all employees participate in short courses (less than 3 months). However 23.8 percent of those attended management and supervisory courses for $3-6$ months and 25 percent attended more than 6 months. The types of training schemes are presented in Table 6 . Only 14.0 percent of the respondents participate in approved training scheme (PROLUS) and 11.0 percent annual training plan scheme (PLT). As shown in the Table 6, the subsidized training scheme $(\mathrm{SBL})$ is considered as main choice of the training schemes.

Table 5:

Type of Training Courses and Duration

\begin{tabular}{|c|c|c|c|c|c|}
\hline & \multirow[b]{2}{*}{ Frequency } & \multirow[b]{2}{*}{ Percent } & \multicolumn{3}{|c|}{ Duration (percent) } \\
\hline & & & $\begin{array}{c}\text { Less than } 3 \\
\text { months }\end{array}$ & $\begin{array}{c}3-6 \\
\text { Months }\end{array}$ & $\begin{array}{l}\text { More than } \\
6 \text { months }\end{array}$ \\
\hline Management and Supervisory & 111 & 36.9 & 38.8 & 23.8 & 25.0 \\
\hline Technical skills & 45 & 15.0 & 73.3 & 6.7 & 20.0 \\
\hline $\begin{array}{l}\text { Occupational health, safety, } \\
\text { and environmental protection }\end{array}$ & 42 & 14.0 & 95.2 & 2.4 & 2.4 \\
\hline Teamwork \& motivation & 41 & 13.6 & 92.7 & 7.3 & 0.0 \\
\hline $\begin{array}{l}\text { Communication \& customer } \\
\text { service }\end{array}$ & 26 & 8.6 & 80.8 & 15.4 & 3.8 \\
\hline Sales and marketing & 17 & 5.6 & 70.6 & 23.5 & 5.9 \\
\hline Others & 19 & 6.3 & 94.4 & 5.6 & 0.0 \\
\hline
\end{tabular}

Notes: $\mathrm{n}=301$ and missing cases $=33$. 
Table 6:

Type of Training Scheme
\begin{tabular}{|l|c|c|}
\hline Scheme & Frequency & Percent \\
& & \\
\hline Subsidized training scheme (SBL) & 201 & 66.8 \\
\hline Approved training scheme (PROLUS) & 42 & 14.0 \\
\hline Annual training plan scheme (PLT) & 35 & 11.6 \\
\hline Training provider agreement scheme (PERLA) & 13 & 4.3 \\
\hline Others & 10 & 3.3 \\
\hline
\end{tabular}

Notes: $\mathrm{n}=301$ and missing cases $=33$.

\section{Effectiveness of the Training}

This section describes perception of employees towards the training programs organized by HRDL. Table 7 indicates the mean of the employees' reactions towards the training programs. The summations of the training content $(\mathrm{M}=3.662, \mathrm{SD}=0.491)$ and overall financing $(\mathrm{M}=3.369, \mathrm{SD}=0.621)$ of the training yielded as moderate level. However, in terms of courses content relevancy and needed for the job were classified as high. The overall trainers quality level $(\mathrm{M}=3.757, \mathrm{SD}=0.5334)$ is also high which is attributed by high score of each items under this variable.

Table 7:

Level One - Training Reactions

\begin{tabular}{|c|c|c|c|}
\hline & Mean & $\begin{array}{c}\text { Std } \\
\text { Deviation }\end{array}$ & Rank \\
\hline Having what you need to do your job & 3.8323 & 0.6590 & High \\
\hline A relevant of courses content & 3.8114 & 0.6130 & High \\
\hline Suitable facilities for teaching and learning & 3.5719 & 0.7589 & Moderate \\
\hline Does not duplicate what you learned previously & 3.4311 & 0.8663 & Moderate \\
\hline Overall training contents & 3.6617 & 0.4906 & Moderate \\
\hline Affordable training for employee and employers & 3.6287 & 0.7433 & Moderate \\
\hline A costly form of training & 3.2814 & 0.8552 & Moderate \\
\hline Received training allowances & 3.1976 & 1.0207 & Moderate \\
\hline Overall financing training & 3.3693 & 0.6211 & Moderate \\
\hline Effective presentation with audio visual & 3.7305 & 0.7509 & High \\
\hline Received good guidance from trainers & 3.7246 & 0.6903 & High \\
\hline Well qualified trainers/ instructors & 3.8084 & 0.6750 & High \\
\hline Industrial based experience trainers/ instructors & 3.7665 & 0.6884 & High \\
\hline Overall trainers quality & 3.7575 & 0.5334 & High \\
\hline
\end{tabular}

Notes: Mean classification: 1.00-2.32 = Low, 2.33-3.66 = Moderate, $3.67-5.00=$ High

In terms of the learning outcomes perception, employees have high level improvement in overall cognitive competencies $(\mathrm{M}=3.8481, \mathrm{SD}=0.5990)$ and overall technical competencies $(\mathrm{M}=3.704, \mathrm{SD}=0.5850)$. All items in cognitive competencies enhancement shown in Table 8 
are high. Meanwhile, only one item in overall technical competencies is classified high. However, the training program does not provide better improvement in employees capability in utilizing current technology $(\mathrm{M}=3.655, \mathrm{SD}=0.713)$ adoption and application of new technologies $(\mathrm{M}=3.620, \mathrm{SD}=0.737)$.

Table 8:

\section{Level 2 - Learning Outcomes}

\begin{tabular}{|l|c|c|c|}
\hline & Mean & $\begin{array}{c}\text { Std } \\
\text { Deviation }\end{array}$ & Rank \\
\hline Enhanced understanding of job responsibilities & 3.9581 & 0.7542 & High \\
\hline Enhanced understanding of task with latest knowledge & 3.8174 & 0.7226 & High \\
\hline Improved understanding of the subject matter & 3.8114 & 0.7536 & High \\
\hline Received hands-on work experience & 3.8054 & 0.7640 & High \\
\hline Overall cognitive competencies & 3.8481 & 0.5990 & High \\
\hline \multicolumn{2}{|l|}{} \\
\hline Able to work independently & 3.8353 & 0.7671 & High \\
\hline Improved ability to utilize current technology & 3.6557 & 0.7132 & Moderate \\
\hline Facilitated adoption and application of new technologies & 3.6198 & 0.7367 & Moderate \\
\hline Overall technical competencies & 3.7036 & 0.5854 & High \\
\hline
\end{tabular}

Notes: Mean classification: 1.00-2.32 = Low, 2.33-3.66 $=$ Moderate, $3.67-5.00=$ High

There are seven items to measure behavioral changes. The mean of these items as shown in Table 9 reveals that the overall employees' level of work commitment $(\mathrm{M}=3.801, \mathrm{SD}=0.568)$ and work respectfulness $(\mathrm{M}=3.745, \mathrm{SD}=0.547)$ are high. Participants of the training show a high improvement in positive attitudes, work eagerness, teamwork within department and punctuality in work. Meanwhile, accuracy, thoroughness and reliability of products and services, compliance to the professional standards and respect to the top management decisions increased at same magnitude. Based on these items, it is indicated that employees have an improvement in the productive workplace behavior.

Table 9:

Level 9 - Behavioral Changes

\begin{tabular}{|c|c|c|c|}
\hline & Mean & $\begin{array}{c}\text { Std } \\
\text { Deviation }\end{array}$ & Rank \\
\hline Positive attitudes towards work & 3.8503 & 0.7071 & High \\
\hline Enhance work eagerness & 3.8383 & 0.6650 & High \\
\hline Improved teamwork collaboration & 3.8108 & 0.7859 & High \\
\hline Improved punctuality in work & 3.7066 & 0.7213 & High \\
\hline Overall work commitment & 3.8011 & 0.5681 & High \\
\hline Improved in accuracy, thoroughness and reliability & 3.8473 & 0.7254 & High \\
\hline Stronger compliance to professional standards & 3.8174 & 0.6481 & High \\
\hline Better respect to the top management decisions & 3.7665 & 0.7266 & High \\
\hline Overall work respectfulness & 3.7448 & 0.5468 & High \\
\hline
\end{tabular}

Notes: Mean classification: 1.00-2.32 $=$ Low, 2.33-3.66 $=$ Moderate, $3.67-5.00=$ High

The total score for employee's job performance is obtained from the summation of responses based on all the 6 item statements shown in Table 10. A higher score indicates a higher level improvement of employee job performance and inversely, a lower score indicates a lower level of employee job performance. The items with highest score in job performance are 
achievement in work target $(\mathrm{M}=3.754, \mathrm{SD}=0.718)$ and improve product quality or service provided $(\mathrm{M}=3.716, \mathrm{SD}=0.767)$ mainly within the company. However Table 10 shows reduce in product or service defects, customer complaints, job hazards and equipment failure rate exhibited a moderate level. Although these items have slightly low mean score, the training impact for job performance $(\mathrm{M}=3.625, \mathrm{SD}=.577)$ is considered moderate.

Table 10:

Level 4 - Result on Employee Job Performance

\begin{tabular}{|l|c|c|c|}
\hline Description & Mean & Std Deviation & Rank \\
\hline Achieve work target & 3.7545 & 0.7184 & High \\
\hline Improve product quality or service provided & 3.7156 & 0.7672 & High \\
\hline Reduce product/service defects & 3.6228 & 0.7197 & Moderate \\
\hline Reduce customers complaints & 3.6198 & 0.7992 & Moderate \\
\hline Reduce job hazards & 3.6018 & 0.7980 & Moderate \\
\hline Reduce equipments failure rate & 3.5240 & 0.7540 & Moderate \\
\hline Overall & 3.6246 & 0.7745 & Moderate \\
\hline
\end{tabular}

Notes: Mean classification: 1.00-2.32 = Low, 2.33-3.66 = Moderate, $3.67-5.00=$ High

\section{Contribution of Training to Employee's Performance}

Table 11 exhibits the result of the estimation of the regression model for training impact on job performance. The overall training impact in model 1 shows a strong statistical significance, with $\rho<0.001$ and the R-square of 0.590 . The model explains 59.0 percent of the variance in job performance. Multicollinearity does not appear to be a serious concern in both models since the VIFs for these variables are below 3.0 (Hair et al., 1998). The hypothesis assumes that the training inputs, learning process and behavioral changes are significantly associated with job performance. Table 11 shows that the training inputs attributes; training content $[\beta=0.113, \rho<.05]$, financing of the training programs $[\beta=0.122, \rho<.05]$ and trainers quality $[\beta=0.214, \rho<.001]$ are positively related to the dependent variable. In term of the learning process, a cognitive competence $[\rho>05]$ is insignificant. While technical skills $[\beta=0.228, \rho<.001]$ is a significant predictor variable. Positive works related behavior mainly respect to the company management $[\beta=0.282, \rho<.001]$ and works commitment $[\beta=0.147$, $\rho<.05]$ are positive and significant predictors of employee's job performance in hotels, resort and ICT companies. In the second model, we add-in demographics factor, academic qualification and works experience. The estimated coefficient of gender $[\beta=0.097, \rho<.05]$ and current work experience $[\beta=0.011, \rho<.05]$ are significant and positively related to the job performance. However, employee's age $[\beta=-0.007, \rho<.01]$ is significant and has an inverse related to the job performance. Meanwhile, years of schooling as proxy for academic qualification are not significant predictor of employee job performance. 
Table 11:

Multiple Regression Analysis of Training Impacts on Employee Job Performance

\begin{tabular}{|c|c|c|c|c|c|c|}
\hline \multirow[t]{2}{*}{ Independent variables } & \multicolumn{3}{|c|}{ Model 1} & \multicolumn{3}{|c|}{ Model 2} \\
\hline & $\beta$ & Std. error & VIFs & $\beta$ & Std. error & VIFs \\
\hline (Constant) & -.192 & .193 & - & -.100 & .224 & - \\
\hline Training content & $.113 * *$ & .053 & 1.619 & $.115^{* *}$ & .053 & 1.631 \\
\hline Financing training & $.122 * * *$ & .035 & 1.126 & $.105 * *$ & .036 & 1.199 \\
\hline Trainers quality & $.214 * * *$ & .052 & 1.852 & $.213 * * *$ & .052 & 1.860 \\
\hline Cognitive competence & -.071 & .050 & 2.105 & -.079 & .049 & 2.113 \\
\hline Technical skills & $.228 * * *$ & .054 & 2.361 & $.232 * * *$ & .053 & 2.366 \\
\hline Respect & $.282 * * *$ & .063 & 2.868 & $.275 * * *$ & .063 & 2.894 \\
\hline Work commitment & $.147 * *$ & .060 & 2.722 & $.160 * *$ & .059 & 2.766 \\
\hline Gender & & & & $.097 * *$ & .043 & 1.094 \\
\hline Age & & & & $-.007 *$ & .004 & 1.095 \\
\hline Years of Schooling & & & & .005 & .005 & 1.594 \\
\hline Current work experience & & & & $.011^{* *}$ & .005 & 1.611 \\
\hline $\mathrm{R}^{2}$ & \multicolumn{3}{|c|}{.590} & \multicolumn{3}{|c|}{.605} \\
\hline Adjusted $\mathrm{R}^{2}$ & \multicolumn{3}{|c|}{.581} & \multicolumn{3}{|c|}{.591} \\
\hline $\mathrm{F}$ & \multicolumn{3}{|c|}{$66.981 * * *$} & \multicolumn{3}{|c|}{$44.831 * * *$} \\
\hline $\mathrm{N}$ & \multicolumn{3}{|c|}{334} & \multicolumn{3}{|c|}{334} \\
\hline
\end{tabular}

Notes: $* * * \rho<.001, * * \rho<.05, * \rho<.01$; Dependent variable job performance.

\section{CONCLUSION}

Management and supervisory and technical skills are the most popular training courses. A subsidized training scheme (SBL) is considered as main choice of the training schemes. Based on participant positive reactions, the training programs were designed match with employee needs and expectation. We have found clear empirical evidence that HRDL training programs improved the knowledge, skills and work behavior of workers. However, the training has moderate impact on employee's job performance. Most of training related variables are positively and significantly associated with employees' job performance except cognitive competence.

\section{REFERENCE}

Al-Khayyat, R.M., and Elgamal, M.A., (1997), "A macro model of training and development: Validation", Journal of European Industrial Training, 2(3): 87-101.

Barnard, Y.F., Veldhuis, G.J., \& Van Rooij, J.C.G.M., (2001), "Evaluation in practice: Identifying factors for improving transfer of training in technical domains", Studies in Educational Evaluation, 27:269-290.

Claros, A.L., Porter, M. E., Martin, S.X and Schwab, K., (2007), "The Global Competitiveness Report 2007-2008”, New York: Palgrave McMillan.

Claros, A.L., Porter, M.E and Schwab, K., (2005), "The Global Competitiveness Report 20052006”, New York: Palgrave McMillan.

Cuthbert, P.F., (1996), "Managing service quality in higher education: Is SERVQUAL the answer? Part 1", Managing Service Quality, 6(2):11-6. 
Dumbrell, T., (2000), "Review of research: Measuring the outcomes of vocational education and training", National Center of Vocational Education and Training (NCVER), Kensington Park: NCVER Ltd.

Fong Chan Onn., (2006), Managing Human Capital in the Globalised Era, Paper presented at the 11 Public Services Conference, INTAN Bukit Kiara, Malaysia, August 21.

Gabbard, L.C.R., (1981), "A costs effectiveness comparison of two types of occupational home economics programs in state of Kentucky". ED215185.

Garelli, S., (2002), "Competitiveness of Nations: The Fundamentals", http://members.shaw.ca/compilerpress 1/Anno\%20Garelli\%20CN\%20Fundamentals.html,(a ccessed July 26, 2008).

Gasskov, V., (2000), "Managing vocational training systems: A handbook for senior administrators", Geneva: International Labor Office (ILO).

George, D \& Mallery, P., (2001), "SPSS for windows step by step: A simple guide and reference, 10.0 update", Boston: Ally \& Bacon.

Grubb, W. N., \& Ryan, P., (1999), "The roles of evaluation for vocational education and training”, London: Kogan Page.

Hair, J.F. Anderson, R.E., Tatham, R.L. \& Black, W.C., (1998), "Multivariate data analysis", New Jersey: Prentice Hall International, Inc.

Hanushek, E.A., (1986), "The economics of schooling: production and efficiency in public Schools", Journal of Economic Literature, XXIV:1141-1177.

Hanushek, E.A., (1997), "Assessing the effects of school resources on student's performance: An Update", Educational evaluation and policy analysis, 19(2):141-164.

Hanushek, E.A., (2002), "The importance of school quality", Research paper, National Bureau of Economic Research, Stanford University.

Holton, E.F., \& Trott, J.W., (1996), "Trends toward a closer integration of vocational education and human resource development", Journal of vocational and technical education, 12(2). http://scholar.lib.vt.edu/ejournals/JVTE/v12n2/holton.html. (Accessed at 2 October 2002).

HRDF., (2008), “Annual report 2007”. Kuala Lumpur: Ministry of Human Resource.

HRDF.,(2005), “General guidelines on the human resources development fund”, Kuala Lumpur: Ministry of Human Resource.

IMD (2008), “World Competitiveness Yearbook 2008”, http://www.imd.ch/research/ publications/wcy/upload/scoreboard.pdf, (accessed May 28, 2008).

Kam, S.K., \& Ka-shing Woo., (1997), "Measuring service quality: A test-retest reliability investigation of SERQUAL", Journal of the Market Research Society, 39(2):381- 396.

Kanapathy, V., (1997), "Labour market issues and skills training: Recent development in Malaysia", Pacific economic cooperation council human resource development task force meeting, Montreal, Canada, 30-31 May.

Ka-shing Woo., (1998), "Developing a scale for measuring service quality perception in distance education", Journal of Customer Service in Marketing \& Management, 4(4):31-45.

Kim, J. E., \& Harris, R.C., (1976), "A costs effectiveness analysis model for secondary vocational education programs", Technical report, Indiana: University, Indianapolis, ED130081.

Kirkpatrik, D. L., (1994), "Evaluating training programs - the four levels”, San Francisco: Berrett-Koehler Publishers, Inc.

Kwan, P.Y.K., \& Ng. P.W.K., (1999), "Quality indicators in higher education: Comparing Hong Kong and China's students", Managerial Auditing Journal, 14(1/2):20-27.

Lynton, R., \& Pareek., (2000), “Training for organizational transformation”, New Dehli: Sage publication. 
Malaysia. (2006), “The Ninth Malaysia Plan 2006-2010”, Putrajaya: Economic Planning Unit Prime Minister's Department.

McCaslin, N.L., (1990), “A framework for evaluating local vocational education programs", Information Series, No 344, Ohio, ED327738.

Nelson, O., (1993), "Conceptual framework for revising the secondary vocational education program evaluation system: Final report”, Center for Vocational, Technical and Adult Education. Stout Menomonie: Wisconsin University.

Porter, M.E., Schwab, K and Martin, S.X., (2006), "The Global Competitiveness Report 2006-2007”, New York: Palgrave McMillan.

Prime Minister's Department., (2008), "Datuk Seri Abdullah Bin Haji Ahmad Badawi Speech at the Mid-Term Review Ninth Malaysia Plan 2006-2010", Putrajaya: Prime Minister's Department.

Schmidt, K., (1998), “A comparative study of two delivery mechanisms of dual vocational training in Germany: Implications for vocational training in the United States", Journal of industrial teacher education, 35(3). $\underline{\text { http://scholar.lib.vt.edu/ }}$ ejournals/JITE/v35n3/Schmidt.html, (Accessed 12 Ogos 2002).

Smith, E., \& Wilson, L., (2002), "School students' views on their working and learning in the workplace”, Sydney: National Center For Vocational Education Research.

Strickland, A., Simons, M., Harris, R., Robertson, I., Harford, M., \& Edwards, A., (2001), "Evaluating on and off the job approach to learning and assessment in apprenticeships and traineeship", Sydney: National Center for Vocational Education Research.

Tan, H.W., and Gill, I. S., (2000), Malaysia, in .Gill, I. S., Fluitman, F and Amit Dar (eds), "Vocational Education and Training Reform", New York: Oxford University Press. 218260

Tamkin, P., (2005), “The contribution of skills to business performance”, Brighton: Institute for employment studies.

Velde C., \& Cooper, T., (2000), "Student's perspectives of workplace learning and training in vocational education", Education and Training, 42(2):83-92.

Ziderman, A., (1997), "National programmers in technical and vocational education: Economic and education relationships", Journal of Vocational Education and Training, 49(3):351-366.

\section{UTJECAJ USAVRŠAVANJA NA UČINKOVITOST ZAPOSLENIKA: SAMOOCJENJIVANJE}

\section{SA}

Stvaranje visoko kvalitetnog, obrazovanog $i$ inovativnog ljudskog kapitala sa snažnim moralnim $i$ etičkim vrijednostima postaje nova smjernica rasta produktivnosti i konkurentnosti zemalja. Stoga je 1992 ustanovljeno Vijeće za razvoj ljudskih resursa (HRDC) kako bi se potaklo cjeloživotno učenje na radnom mjestu u svrhu poboljšanja produktivnosti rada, transfera tehnologije i inovacija. 2002 je preimenovano u HRDL (Human Resource Development Limited). Svi zaposlenici članovi HRDL-a mogu aplicirati za stipendiranje usavršavanja. Zadnjih godina je ukupan broj mjesta i iznosa odobrenih za financiranje usavršavanja u porastu. Ovaj rad istražuje u kojoj mjeri programi usavršavanja unapređuju znanja $i$ sposobnosti zaposlenika te njihovo ponašanje na poslu $i$ učinkovitost, kao i koji važni čimbenici vezani uz usavršavanje utječu na učinkovitost. Rad počiva na podacima prikupljenima anketiranjem 1200 zaposlenika (odgovorilo ih je $45.8 \%$ ) hotela, ljetovališta $i$ ICT poduzeća u četiri odabrane države. Iz odgovora je vidljivo da je 73\% zaposlenika prošlo razne programe usavršavanja koje je koordinirao HRDL. Rezultati pokazuju da, generalno gledano, programi usavršavanja poboljšavaju znanje, sposobnosti i pozitivno poslovno ponašanje zaposlenika. Višestruka regresijska linearna analiza podržava hipotezu da varijable vezane uz usavršavanje imaju pozitivan utjecaj na učinkovitost zaposlenika s izuzetkom kognitivne kompetencije.

Ključne riječi: usavršavanje, učinkovitost, kvaliteta zaposlenika 